\title{
СРАВНИТЕЛЬНАЯ ХАРАКТЕРИСТИКА ПРОТИВОВАРРОАТОЗНОЙ ЭФФЕКТИВНОСТИ РАСТИТЕЛЬНЫХ АКАРИЦИДОВ В РАЗЛИЧНЫЕ ПЕРИОДЫ ГОДА
}

\section{Рецензент - доктор ветеринарных наук В. В. Лемещенко}

Проведено аналіз противарроатозної ефективності рослинних акарицидів (порошок трави полину гіркого, порошок листя евкаліпта, дим кореня хріну) при обробиі бджсолиних сімей перед головним медозбором (літо) $i$ перед формуванням зимового клубу (осінь). Акарицидні обробки з використанням рослинних препаратів на основі трави полину гіркого, листя евкаліпта й кореня хріну низькоефективні за осінньої обробки проти варроатозної інвазії. Порошок трави полину гіркого ефективний екологічно чистий засіб для боротьби з варроатозом перед головним медозбором. Порошок листя евкаліпта має 55,94 1 10,21\% ефективність за обробки бджолиних сімей перед головним медозбором. Корінь хріну низькоефективний для боротьби з варроатозною інвазією.

Ключевые слова: варроатоз, пчёльл, растительные акарицицыл.

Постановка проблемы. Особую проблему в технологии получения продуктов пчеловодства вызывает увеличение количества неблагополучных пасек по различным заболеваниям. Существенным препятствием развития пчеловодства являются заразные болезни пчел, и в первую очередь, варроатоз, получивший в последние десятилетия широкое распространение на пасеках многих стран, в том числе и в Украине [7].

Анализ основных исследований и публикаций, в которых описано решение проблемы. Клещ Varroa jacobsoni Oudemans наносит вред взрослым особям пчелиной семьи в течение всего года, а в активный период - и расплоду. В процессе паразитирования на медоносной пчеле создает благоприятные условия для проникновения в ее организм патогенной микрофлоры возбудителей бактериальных болезней [2, 5, 8, 9, 13].

Ассоциативное течение инфекции и инвазии обостряет патогенный процесс, наносит существенный экономический ущерб и, как правило, семьи погибают [3].

Отечественной и зарубежной наукой и практикой накоплен большой опыт по организации зоотехнических, лечебных, профилактических мероприятий в пчеловодстве. Несмотря на наличие разнообразных акарицидных средств, изучение и использование нового поколения препаратов остается весьма актуальной задачей ввиду повышения устойчивости возбудителей заболеваний пчел к имеющимся лекарственным средствам [1, 10]. Кроме того применение химических акарицидов способствует загрязнению продукции пчеловодства их остатками и метаболитами $[11,17]$, токсическому и побочному действию препаратов на пчел $[6,16]$.

На эффективность препаратов большое влияние оказывают погодные и природно-климатические условия [4, 12]. Вместе с тем мало данных об эффективности акарицидов, применяемых для лечения пчел в различных природноклиматических зонах Украины, в том числе и в АР Крым.

В связи с этим необходимо изучение эффективности лекарственных средств и дальнейшее усовершенствование препаратов и методов их применения, прежде всего на региональном уровне [15].

Цель исследований - провести анализ противоварроатозной эффективности растительных акарицидов (порошок травы полыни горькой, порошок листьев эвкалипта, дым корня хрена) при обработке пчелиных семей перед главным медосбором (лето) и перед формированием зимнего клуба (осень).

Задача исследований - изучить акарицидную эффективность свойств растительных препаратов (на основе травы полыни горькой, листьев эвкалипта и корня хрена) против варроатозной инвазии в различные периоды года.

Материал и методы. Исследования проводили на пчелиных семьях, принадлежащих Крымскому предприятию «Крымпчелопром» в 20112012 году. Для опыта по принципу аналогов отобрали 20 пчелиных семей и разделили их на четыре группы, по 5 в каждой. Формирование групп проводили в соответствии с «Методическими указаниями к постановке экспериментов в пчеловодстве» [14].

Осеннюю обработку провели с 24 октября по 9 ноября 2011 года на пчёлах, принадлежащих к 


\section{ВЕТЕРИНАРНА МЕДИЦИНА}

карпатской породе, с объемом гнезда - 10 рамок Лангстрота, возраст маток-сестер один год и четыре месяца, сила семей - 10 улочек, количество корма 20 кг, экстенсивность инвазии - II уровень, содержащихся в ульях Лангстрота в одинаковых условиях на одной точке.

Акарицидную обработку насекомых перед главным медосбором проводили с 1 по 14 июня 2012 года на пчёлах, принадлежащих к карпатской породе, с объемом гнезда - 20 рамок Лангстрота, возраст маток-сестер - один год, сила семей - 20 улочек, количество корма - 20 кг, экстенсивность инвазии - II уровень, содержащихся в ульях Лангстрота в одинаковых условиях на одной точке.

В качестве акарицидного препарата для обработки пчелосемей первой группы применяли порошок травы полыни горькой по 5 г на улочку. Для этого полынь помещали в марлевый мешок на 14 дней, который расстилали тонким слоем на рамках над гнездом и накрывали полиэтиленом.

Для акарицидной обработки пчелосемей второй группы использовали порошок листьев эвкалипта по 7,5 г на улочку. Его также помещали в марлевый мешок на 14 дней, расстилали тонким слоем на рамках над гнездом и накрывали полиэтиленом.

Третью группу пчелосемей окуривали дымом из высушеного корня хрена. С этой целью в разгоревшийся дымарь помещали 30 г корней хрена и делали по 1 дмуху на улочку в леток каждой семьи.

В каждой группе на дно улья поместили листы белой бумаги, смазанные вазелином для фиксации осыпающихся варроатозных клещей.

Акарицидную эффективность препаратов рассчитывали по формуле:

$Э \phi=100-Э И_{2} / Э И_{1} \times 100$, где:

Эф - акарицидную эффективность препарата;

ЭИ

ЭИ 2 - экстенсивность инвазии после лечения;

100 - коэффициент выраженности результата, \%.

Результаты исследований. Наши наблюдения показали, что при обработке пчелиных семей против варроатоза перед формированием зимнего клуба (осенью) акарицидная эффективность порошка травы полыни горькой в первой группе составила $29,78 \pm 2,77$ \%. При этом регистрировали слабое осыпание клещей в течение всего периода применения препарата (см. рис.).

Во второй группе наблюдали также слабое осыпание клещей в течение всех 14 дней использования порошка листьев эвкалипта. Акарицидная эффективность данного растительного препарата составила 23,03 $\pm 3,49 \%$.

В третьей группе сразу после проведения акарицидной обработки отмечали сильное возбуждение пчелиных семей и осыпание клещей. Акарицидная эффективность корней хрена составила $35,1 \pm 2,92 \%$.

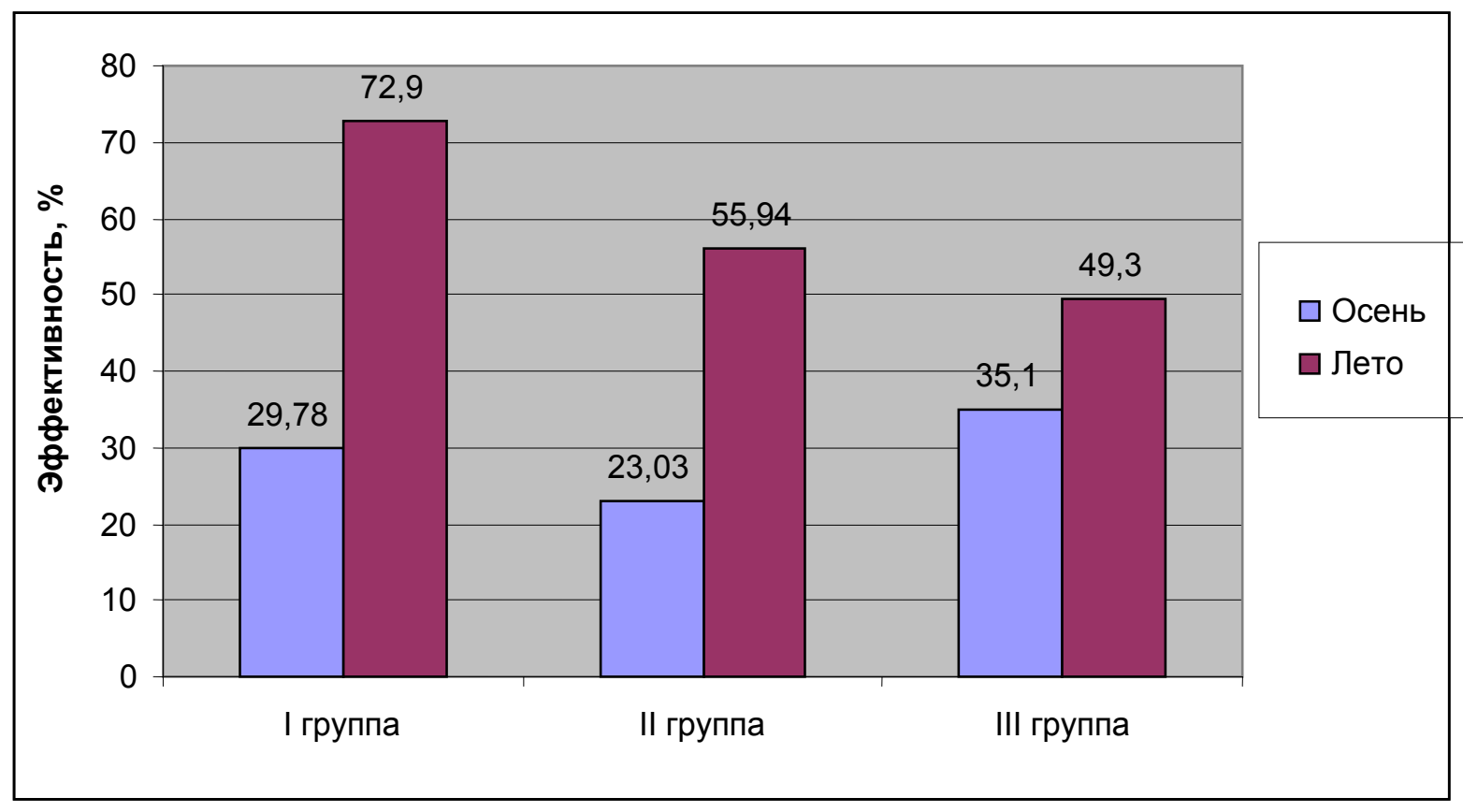

Рис. Противоварроатозная эффективность растительных препаратов в различные сроки обработки 


\section{ВЕТЕРИНАРНА МЕДИЦИНА}

После проведения обработок пчелиных семей против варроатоза перед главным медосбором (лето) были получены следующие данные.

Использование порошка травы полыни горькой привело к сильному осыпанию клещей на вторые сутки после внесения препарата в улей. Впоследствии отмечали слабое осыпание паразитов в течение всего периода применения препарата. Акарицидная эффективность порошка

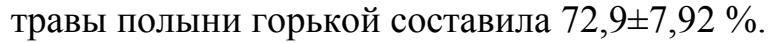

После применения в качестве акарицидного средства порошка листьев эвкалипта регистрировали слабое осыпание варроатозных клещей в течение всех 14 дней. Акарицидная эффективность данного растительного препарата составила $55,94 \pm 10,21 \%$.

В третьей группе сразу после проведения акарицидной обработки отмечали сильное возбуждение пчелиных семей и осыпание клещей. Акарицидная эффективность корней хрена составила $49,3 \pm 5,39 \%$.

\section{БИБЛИОГРАФИЯ}

1. Батуев Ю. М. Устойчивость клеща Варроа к препаратам / Ю. М. Батуев, В. А. Дриняев, Л. К. Березина [и др.] // Пчеловодство. - 2010. - №1. C. 24-25.

2. Веригін I. Пасіка без кліща Вароа // Пасіка. 2009. - №9. - С. 6-7.

3.Закиров H. И. Технологические аспекты производства продуктов пчеловодства при смешанном течении варроатоза и европейского гнильца : автореф. дисс. ... канд. с.-х. наук. 06.02.04: «Частная зоотехния, технология производства продуктов животноводства» / Уфа. - 2004. - 135 с.

4.Иванов Ю. А. Правильно используйте лечебные препараты // Пчеловодство. - 2005. № 6. - С. 31-32.

5. Игнатьева Г. И. Тактика борьбы с варроатозом пчёл / Г. И. Игнатьева, В. Н. Мельник, А. Б. Сохликов, А. И. Муравская // Пчеловодство. - 2004. № 1. - С. 32-33.

6. Игнатьева Г. Варроатоз пчел // Ветеринария. - 2005.- №2. - С. 14-17.

7.маслій I. Стан ветеринарно-санітарного благополуччя пасік / I. Г. Маслій // Пасіка. 2009. - №5. - С. 11.

8. Приймак Г. Тримаймо кліща Вароа під контролем / Г. М. Приймак, В. О. Паливода // Пасіка. - 2011. - №1. - С. 12-13.

9. Приймак Г. Проти кліща варроа - комплексний підхід / Г. М. Приймак // Пасіка. - 2012. - №3.
Из рисунка видно, что противоварроатозная эффективность порошка полыни горькой при обработке пчелиных семей перед главным медосбором (лето) выше на 43,12 \%, чем при осенней обработке, порошка листьев эвкалипта - выше на $32,91 \%$, корней хрена - на 14,2\%.

\section{Выводы:}

1. Акарицидные обработки с использованием растительных препаратов на основе травы полыни горькой, листьев эвкалипта и корня хрена являются низкоэффективными при осенней обработке против варроатозной инвазии.

2. Порошок травы полыни горькой является эффективным экологически чистым средством для борьбы с варроатозом перед главным медосбором.

3. Порошок листьев эвкалипта обладает $55,94 \pm 10,21 \%$ эффективностью при обработке пчелиных семей перед главным медосбором.

4. Корень хрена является низкоэффективным средством для борьбы с варроатозной инвазией.

- C. 22-23.

10. Руденко $C$. Резистентність кліща Varroa до лікувальних препаратів / С. Руденко // Український пасічник. - 2012. - №6. - С. 33-35.

11. Сохликов A. Б. Получение экологически чистой продукции / А. Б. Сохликов, Г. И. Игнатьева // Пчеловодство. - 2005. - № 1. - С. 26-27.

12. Сохликов А. Б. Препараты на основе амитраза / А. Б. Сохликов, Г. И. Игнатьева // Пчеловодство. -2006 . - № 6. - С. 30-31.

13. Сохликов $A$. Причина гибели пчел - варроатоз / А. Б. Сохликов, Г. И. Игнатьева, Е. Т. Попов // Ветеринария. - 2008. - №3. - С. 33-36.

14. Шагун Я. Л. Методичесткие указания к постановке экспериментов в пчеловодстве / Я. Л. Шагун - М. : Россельхозакадемия, 2000. $10 \mathrm{c}$.

15. Шнайдер $A$. A. Разработка новых методов применения акарицидов при варроатозе пчел и их эффективность на пасеках Тюменской области: автореф. дисс... к.вет.н. 03.00.19: - «Паразитология», Тюмень, 2009. - 21 с.

16. Kasprzak S. Pszczory a leki / S. Kasprzak, A. Hartwig // Pszczelarstwo. - 2005. - № 8. - P. 1013.

17. Pechhacker H. Amitraz-Verbot in Osterreich / H. Pechhacker, R. Moosbeckhofer // Bienenvater. 2002. - № 10, T. 123. - P. 9-12. 